\title{
Entrevista
}





\section{Um defensor dos direitos políticos do cidadão brasileiro}

FÁBIO KONDER COMPARATO

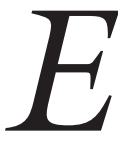

studos Avançados entrevistou o Prof. Dr. Fábio Konder Comparato, titular aposentadoda disciplina Filosofia do Direito da Faculdade de Direito da Universidade de São Paulo, instituição de que é Professor Emérito. É doutor em Direito pela Universidade de Paris e doutor Honoris Causa pela Universidade de Coimbra. Defensor dos direitos humanos, tem denunciado violações praticadas ao longo das últimas décadas. Foi criador da Escola de Governo. Suas principais obras são Muda Brasil. Uma Constituição para o desenvolvimento democrático (1986), Para viver a democracia (1989), A afirmação histórica dos direitos humanos (1999), Ética (2006) e Ruma à Justiça (2010). (Alfredo Bosi)

\section{Formação jurídica}

ESTUDOS AVANÇADOS - O que ficou de sólido da sua formação jurídica universitária?

Fábio Konder Comparato - Durante o meu curso de bacharelado em direito na USP, entre 1955 e 1959, nada me foi ensinado quanto ao método de estudo. Aprendi, sem dúvida, os conceitos básicos e a forma de utilizá-los. O que recebi, portanto, não foi propriamente uma educação jurídica, mas uma instrução técnica, centrada em torno da lógica normativa. Faltou, sobretudo, assinalar a íntima ligação do direito com os valores éticos e a sua inserção no quadro da História das Civilizações. Com raras exceções, entre as quais convém citar Goffredo da Silva Telles Jr., os professores não se alçavam acima do nível mediano, fazendo questão de exibir uma erudição livresca. Desconheciam a sábia advertência que Montaigne fez a todo educador, em relação aos seus discípulos: il vaut mieux avoir une tête bien faite, que bien pleine.

Curiosamente, o que de mais sólido ficou para mim desses anos de bacharelado nada teve a ver com o ensino do direito: foi a descoberta do mundo da pobreza. Ao contrário dos demais estudantes católicos da época, ao invés de me filiar à JUC (Juventude Universitária Católica), preferi, juntamente com alguns colegas, até hoje meus grandes amigos, ingressar na Sociedade São Vicente de Paulo, associação criada por Frederico Ozanam na França no século XIX. A missão de cada um dos membros dessa associação consiste em ligar-se a uma família pobre, visitando-a semanalmente para auxiliá-la em suas necessidades básicas de toda espécie. Desses anos de prática vicentina restou-me a sólida convicção de que o primeiro dever de justiça, em nosso país, consiste em fazer o possível para reduzir ao máximo a desigualdade social. 


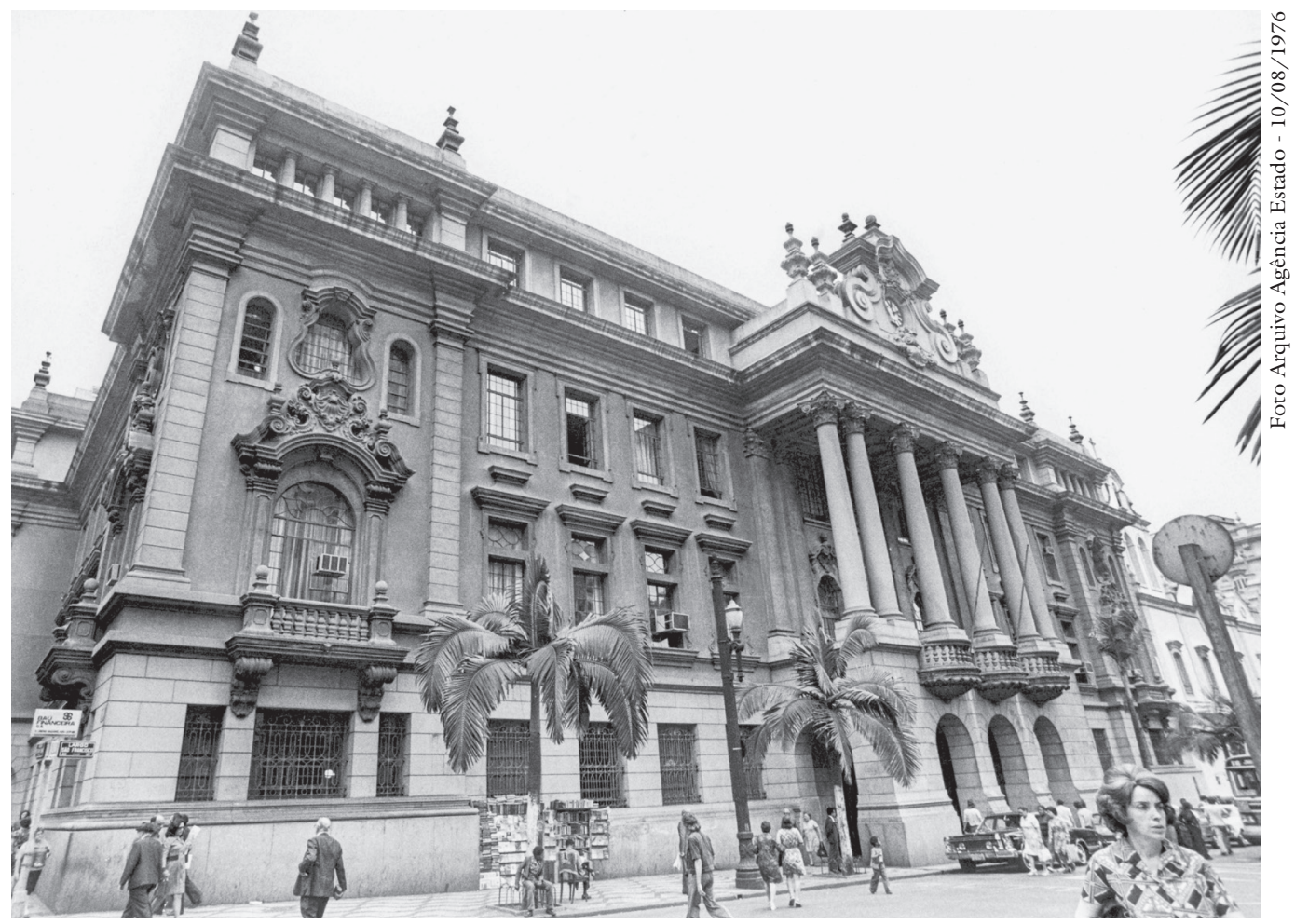

Fachada da Faculdade de Direito do Largo do São Francisco da USP.

Ao chegar a Paris em 1960 para fazer o curso de doutorado em direito, a extraordinária riqueza da cultura europeia penetrou-me desde logo por todos os poros. Durante os anos de pós-graduação na França, até minha defesa de tese em 1963, aprendi, sobretudo, que o trabalho intelectual funda-se na reflexão crítica e não na mera coleta de citações, como sempre se fez entre nós, por força da tradição jesuítica e coimbrã. Notei, contudo, alguns aspectos negativos no sistema intelectual francês. De um lado, o excessivo formalismo e rigor cartesiano; basta dizer que se exigia, para as teses apresentadas na Sorbonne (Faculdade de Filosofia, Ciências e Letras), que tivessem três partes, e na Faculdade de Direito apenas duas. De outro lado, o nacionalismo intelectual: pelo menos no campo jurídico, só eram considerados os autores franceses.

\section{EA - Qual o núcleo conceitual e propositivo da sua tese sobre as sociedades anônimas?}

$F K C$ - Antes de mais nada, é preciso explicar por que me encaminhei para os estudos de direito comercial. Tudo começou durante o doutorado em Paris. Naquela época, como tantos outros jovens universitários brasileiros, eu vivia fascinado por Celso Furtado e preocupado em lutar contra a separação mundial entre países desenvolvidos e subdesenvolvidos. Em 1959, assisti encantado, na Faculdade de Direito da USP, a uma conferência de Georges Burdeau, ilustre professor de direito constitucional e ciência política da Universidade de Paris. Resolvi, então, propor o estudo de tais matérias no programa de bolsa de estu- 


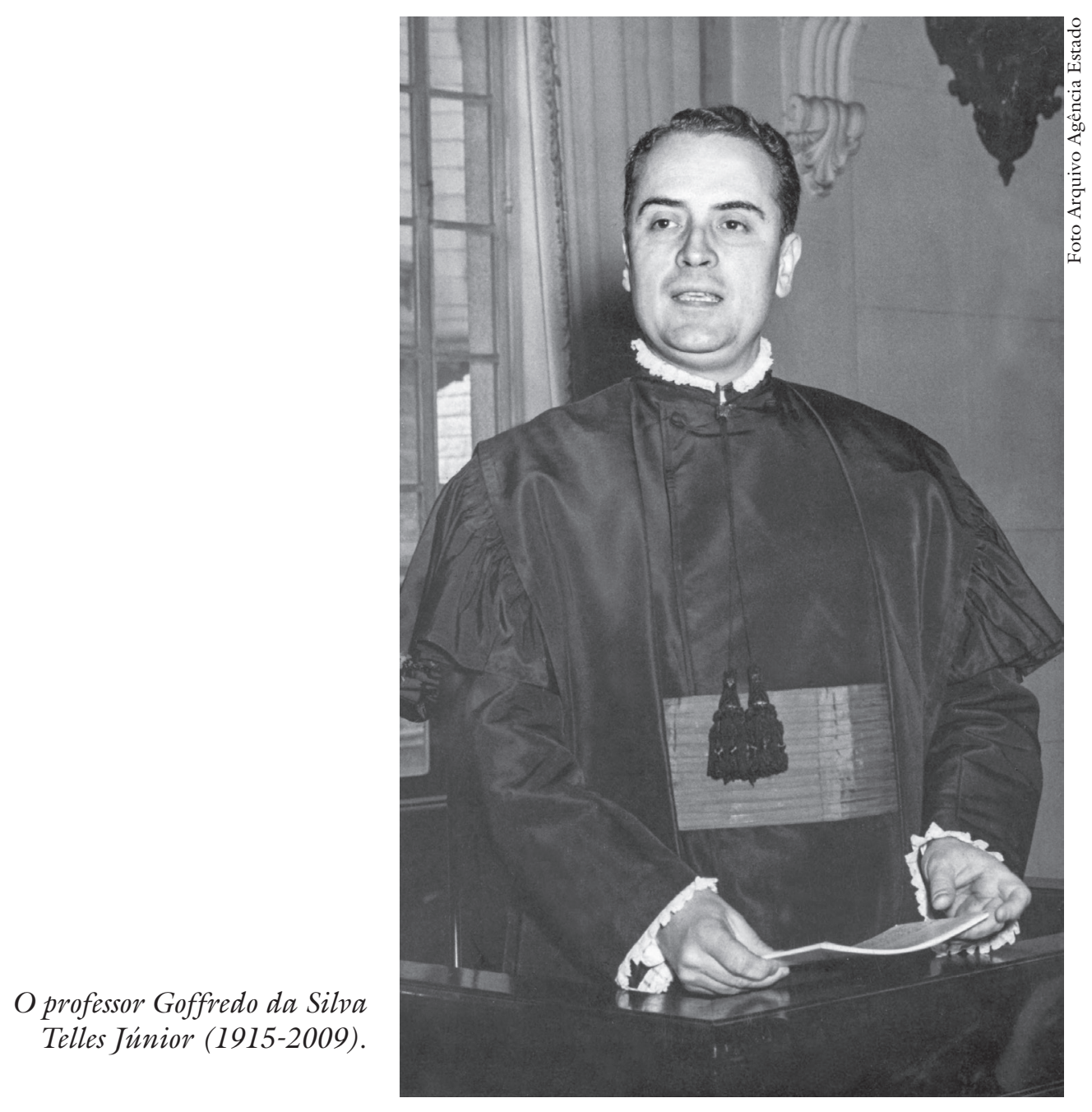

dos patrocinado pelo consulado francês. Ao chegar em Paris, porém, verifiquei o óbvio: o programa de estudos que me propunha fazer era totalmente estranho à minha preocupação em trabalhar em favor do desenvolvimento do Brasil. À época, ainda não se ensinava o direito econômico (o direito das políticas econômicas) nos cursos jurídicos. Só me restava, então, a possibilidade de estudar a matéria jurídica que eu supunha (erroneamente) mais próxima dele. Entendi que seria o direito comercial. Ao escolher um tema de tese, decidi sair do ramerrão dogmático e selecionar um assunto de teoria geral do direito privado, que fora mencionado nas aulas de direito comercial em São Paulo. A teoria em questão, elaborada por um professor alemão do século XIX, Alois Brinz, cuja obra em edição original (em caracteres góticos!) pude consultar na excelente Biblioteca Nacional de Paris, era totalmente desconhecida no meio acadêmico francês. Foi essa, creio eu, a principal razão de minha tese ter sido premiada.

Sem dúvida, como diz o ditado, Deus escreve direito por linhas tortas. Se eu tivesse feito meu doutorado em direito constitucional, certamente ele não 
teria sido reconhecido pela Faculdade de Direito da USP às vésperas do golpe de 1964, pois eu havia colaborado, desde a França, com artigos para um jornal considerado altamente subversivo pelo grupo reacionário da Faculdade. De qualquer maneira, ao estudar o direito comercial, meus olhos se abriram, pela primeira vez, para a realidade do capitalismo, que à época eu ainda não compreendia ser uma autêntica civilização e não mero sistema econômico. Só vim a sustentar essa ideia recentemente, em artigo publicado nesta Revista sob o título "Capitalismo: civilização e poder".

A tese de meu concurso de titularidade em direito comercial, sobre o poder de controle na sociedade anônima, foi meu primeiro exame do onipresente poder capitalista; poder nunca ostensivo, mas sempre oculto ou dissimulado, e que domina não apenas o mercado, mas toda a esfera política. Graças à análise desse poder, comecei a compreender a essencial duplicidade do mundo jurídico capitalista. Há sempre, por trás do direito oficial, outro sistema jurídico, nunca formalmente reconhecido, mas sempre efetivo e poderoso. Essa duplicidade institucional ocorre, por exemplo, no sistema da mal chamada "democracia representativa". Digo mal chamada, pois, como Rousseau bem advertiu, se a democracia é o regime da soberania do povo, somente esse pode exercê-la, pois a delegação do poder supremo equivale à sua alienação. $\mathrm{O}$ povo soberano designa representantes para as tarefas de governo, que ele próprio não pode exercer; mas as decisões desses representantes podem ser revistas pelo povo, e eles próprios destituídos por votação popular (recall). Ora, o gênio do capitalismo consistiu em defender abertamente a absurda representação do poder soberano, como única forma possível de democracia no mundo moderno. Por essa forma, encobriu-se o verdadeiro poder de controle do grande empresariado sobre o conjunto dos órgãos políticos do Estado, inclusive o Judiciário! Em suma, no mundo jurídico capitalista há sempre um Direito e um Avesso, como procurei mostrar, com referência ao Brasil, em artigo com esse mesmo título, também publicado nesta Revista.

Camões ilustrou a duplicidade demoníaca do poder do dinheiro - como a serpente do Gênesis! - em estrofe famosa do Canto VIII de Os lusíadas:

Este interpreta mais que sutilmente

Os textos; este faz e desfaz leis;

Este causa os perjúrios entre a gente,

E mil vezes tiranos torna os reis;

Até os que só a Deus onipotente

se dedicam, mil vezes ouvireis

Que corrompe este encantador, e ilude,

Mas não sem cor, contudo, de virtude! 


\section{Direitos humanos}

EA-O que o levou a ser militante dos direitos humanos a partir da década de 1970 e, precisamente, no âmbito da Comissão de Justiça e Paz de nossa arquidiocese?

FKC - Em meados de 1971, D. Paulo Evaristo Arns, que havia sido nomeado arcebispo de São Paulo em outubro do ano anterior, convidou-me a integrar a Comissão de Justiça e Paz, que acabara de fundar. Disse-lhe, um tanto embaraçado, que minha fidelidade à Igreja estava longe de ser exemplar. D. Paulo retrucou, de imediato, que esse fato não tinha importância. "O que eu quero saber", disse ele, "é se você está disposto a defender intransigentemente a dignidade da pessoa humana contra os abusos que vêm sendo praticados pelas autoridades políticas". Tive, logo em seguida, a oportunidade de indicar Margarida Genevois para fazer parte da Comissão. Ela foi o seu coração atuante.

A partir do trabalho na Comissão de Justiça e Paz da arquidiocese, minha orientação intelectual no campo jurídico mudou sensivelmente. Enveredei progressivamente pelo campo do direito constitucional, dos direitos humanos e da filosofia do direito. Nessa mudança de rumo, fui muito influenciado pela querida amiga professora Maria Victoria de Mesquita Benevides. Em 1999 saiu a primeira edição de meu livro A afirmação histórica dos direitos humanos, reeditado em 2013 pela oitava vez. Nos últimos anos de minha docência na Faculdade de Direito, tive ocasião de criar, no bacharelado, o primeiro curso regular e autônomo de direitos humanos. Até então (e na grande maioria das Faculdades de Direito), essa matéria fazia parte do direito constitucional, e tinha, portanto, um âmbito bem acanhado: não só havia a limitação do estudo dos direitos humanos ao texto constitucional, segundo o lamentável método do positivismo jurídico, como ainda ignorava-se todo o sistema internacional de direitos humanos. Hoje, a Faculdade de Direito da USP já conta, também, com um curso de pós-graduação nesse campo.

$E A$ - Por que você redigiu uma Constituição alternativa por ocasião do debate que resultou na promulgação da Constituição de 1988? Em que medida você agora julga um passo adiante esta última Carta Magna?

$F K C$ - Na agonia do regime empresarial-militar, eu, como tantos outros brasileiros, alimentava a ingênua convicção de que o nosso país tornar-se-ia uma autêntica Democracia. Era indispensável, para tanto, deixar de tratar apenas retoricamente do assunto e organizar as instituições próprias do regime democrático. Com esse objetivo, propus, entre outras medidas, o reconhecimento constitucional do plebiscito e do referendo popular, como instrumentos indispensáveis ao funcionamento efetivo da soberania do povo. Além disso, sempre fiel aos ensinamentos de Celso Furtado, incluí no anteprojeto de Constituição o Poder de Planejamento, autônomo em relação aos demais Poderes. Pequei, no entanto, por ingenuidade. Ignorava, então, que todo regime político funda-se numa mentalidade coletiva, feita de valores éticos e costumes bem assentados; e que, desde o Descobrimento, sempre vivemos impregnados de uma mentalidade animada pelos valores capitalistas, isto é, antirrepublicanos e antidemocráticos. 
Não me dei assim conta de que o novo regime, instaurado pela Constituição de 1988, embora deixando de ser militar, permaneceria empresarial como sempre fora, não obstante a enganosa fachada democrática constitucional.

EA - O que nos ensina o episódio da privatização da Vale do Rio Doce em um contexto não só nacional, mas internacional?

$F K C$ - A grande lição desse caviloso episódio é a confirmação da famosa sentença de Frei Vicente do Salvador, na sua História do Brasil, editada em 1627: "Nem um homem nesta terra é repúblico, nem zela e trata do bem comum, senão cada um do bem particular". A maior empresa mineradora do Brasil e uma das maiores do mundo, a qual detinha o mais completo mapa geológico do nosso território, foi vendida na bacia das almas, por dois tostões de mel coado, como se dizia no meu tempo de juventude. Participei, com muita honra, da ação popular concebida pelo professor Celso Antonio Bandeira de Melo, destinada a anular esse crime de lesa-pátria. O ínclito Poder Judiciário, contudo, chamado a julgá-la, decidiu simplesmente abaixar a cabeça.

\section{Comissões da verdade}

$E A$ - Você poderia rememorar os principais lances da sua luta pelo respeito à memória dos perseguidos pela ditadura militar? Qual a sua apreciação das atuais comissões da verdade?

FKC - Minha atuação como advogado de vítimas do regime empresarial-militar começou em 1999, quando um ex-colega do curso de bacharelado, velho militante comunista, veio ao meu escritório com Inês Etiene Romeu, única sobrevivente da tenebrosa Casa da Morte, em Petrópolis. Ela contou-me que, tendo sido presa em 1971 em São Paulo pelos agentes do delegado Fleury, foi recolhida ao Dops e lá bestialmente torturada. Levada em seguida ao Rio de Janeiro, foi entregue aos agentes militares que prosseguiram nos tormentos, até que Inês, desesperada, resolveu pôr fim à vida. Simulou, então, um encontro com companheiros da subversão em determinado subúrbio do Rio e, lá chegando, quando os guardas se afastaram, jogou-se diante de um ônibus. Não teve sorte: saiu muito fraturada, mas com vida. Após um período de tratamento no Hospital Militar do Rio, foi transferida para a Casa da Morte em Petrópolis, onde permaneceu cerca de seis meses, sendo torturada praticamente todos os dias e estuprada por três vezes. Por sorte, seu pai, que era oficial reformado das Forças Armadas, tomou conhecimento da sua localização e informou o ministro do Exército, seu antigo colega de Escola Militar. O ministro não tinha a menor ideia da existência dessa masmorra e pediu informações a seus subordinados. Com isso, naquele mesmo dia, Inês foi transferida de automóvel para Belo Horizonte e jogada por cima do muro na casa de seus pais. O advogado da família teve então a boa ideia de apresentar Inês de imediato ao juiz competente, para que ela fosse oficialmente presa, escapando com isso de ser morta pelos agentes da repressão. Foi julgada e condenada, permanecendo na prisão até a concessão da anistia em 1979. 
Inês disse-me que queria propor uma ação judicial contra o Estado brasileiro, em razão desses fatos. Imaginando que ela tencionava receber uma indenização, ponderei que isso seria impossível por força da prescrição, que é a perda do direito de agir em juízo pelo decurso do tempo. (Alguns anos depois, a jurisprudência brasileira passou a reconhecer que as ações referentes a direitos humanos são imprescritíveis.) Ao ouvir essa minha ponderação, Inês disse-me que não queria receber nem um tostão do Estado brasileiro, pois esse dinheiro viria do povo, já amplamente escorchado. O que desejava era, tão só, que a Justiça brasileira reconhecesse oficialmente os horrores a que fora submetida por agentes do Estado, cujos vencimentos eram pagos com dinheiro público, isto é, dinheiro arrecadado do povo. Recebi a lição, e ingressei em juízo com uma ação meramente declaratória contra a União Federal, pedindo que fossem judicialmente reconhecidas as gravíssimas violações de direitos humanos, de modo a dar à minha constituinte uma ampla satisfação moral. Em minha incorrigível ingenuidade, acreditava que o Estado brasileiro não contestaria a demanda, pois os fatos abomináveis nela narrados haviam acontecido sob o regime anterior à Constituição de 1988. Falei a esse respeito com o Advogado Geral da União, que era à época meu amigo. Pois bem, a União não somente contestou a ação, como alegou em sua defesa razões ridículas e ineptas. Depois disso, cortei relações com o então responsável pela defesa judicial da União. A ação foi julgada procedente em primeira instância. A União Federal apelou, mas o Advogado Geral da União, sem dúvida com dor na consciência, determinou a desistência da apelação, encerrando-se o processo em 2004.

Muito embora o oligopólio empresarial dos meios de comunicação de massa não desse a menor notícia desse processo, o ganho de causa de Inês Etiene Romeu difundiu-se entre as vítimas do regime terrorista instaurado em 1964. Em 2005, fui procurado por Janaina de Almeida Teles, que me relatou o horrível período de vexames e torturas sofrido por seus pais e sua tia no DOI-Codi de São Paulo, então sob o comando do (na época) major Ustra. Ingressei com o mesmo tipo de ação utilizado no caso de Inês Etiene Romeu, obtendo ganho de causa na primeira instância em São Paulo, com uma magnífica sentença da lavra do Juiz Gustavo Santini Teodoro. Essa sentença foi confirmada em agosto de 2012 por unanimidade, no Tribunal de Justiça de São Paulo.

Posteriormente, procuraram-me alguns familiares do jornalista Luiz Eduardo da Rocha Merlino, que morreu sob torturas no DOI-Codi de São Paulo também em 1971. Ajuizei, como nos outros casos, uma ação declaratória contra o hoje coronel Ustra, mas ela foi surpreendentemente julgada incabível. Ingressei então com uma ação condenatória, pedindo que a Justiça fixasse o montante adequado da indenização devida por Ustra aos familiares de Merlino. Essa segunda demanda foi julgada procedente pela juíza Cláudia de Lima Menge, em sentença de agosto de 2012. Agora, aguarda-se o julgamento da apelação interposta pelo réu. 


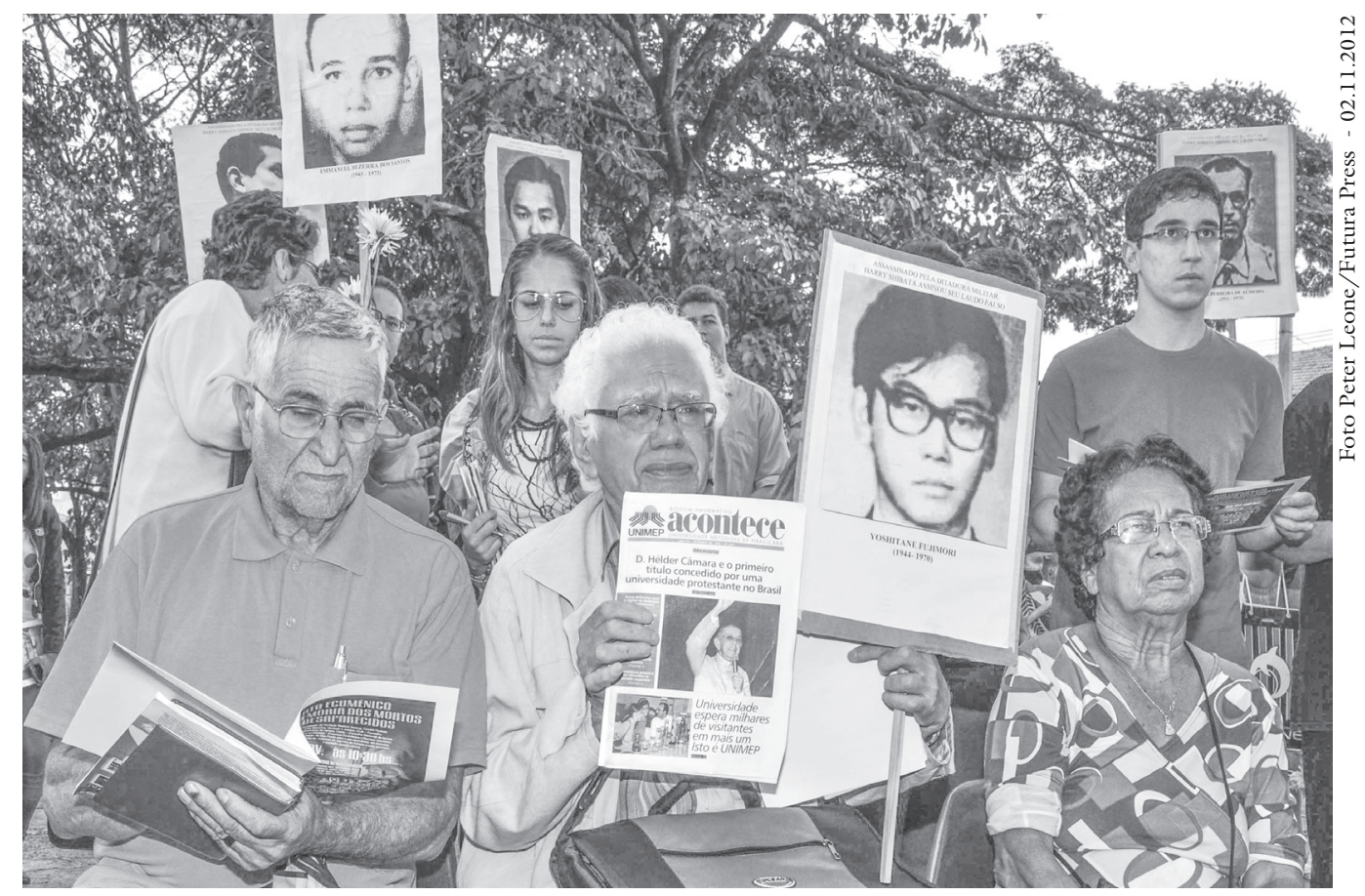

Ato ecumênico realizado em São Paulo em memória das vítimas de violência da repressão.

Tanto na ação da família Teles como nas ações intentadas em nome dos familiares de Luiz Eduardo da Rocha Merlino, contei com o valioso auxílio dos advogados Claudineu de Melo e Aníbal Castro.

O Ministério Público Federal também intentou algumas ações civis públicas contra o coronel Ustra, mas elas foram rejeitadas liminarmente em primeira instância. Posteriormente, porém, os procuradores da República decidiram ajuizar ações penais contra alguns líderes da repressão militar daquele período, malgrado a lei de anistia de 1979, e tais ações começam a ser julgadas procedentes em primeira instância, por se tratar de crimes permanentes ou continuados.

Mas isso me leva a outra consideração. Em 2008, fazendo valer minha condição de membro honorário do Conselho Federal da Ordem dos Advogados do Brasil, propus ao Conselho, que o aceitou, fosse ajuizada perante o Supremo Tribunal Federal uma ação visando a dar à lei de anistia de 1979 uma interpretação conforme aos princípios da Constituição de 1988 e ao sistema internacional de direitos humanos. Pelo disposto no art. $5^{\circ}$, inciso XLIII da Constituição, a tortura é um crime inafiançável e insuscetível de graça e anistia. Como é de conhecimento geral no mundo jurídico, a Constituição nova revoga de pleno direito todas as disposições legais anteriores, com ela incompatíveis. O Supremo Tribunal Federal aplicou exatamente esse princípio em 2009, ao julgar automaticamente revogada, com a entrada em vigor da atual Constituição, a lei de imprensa promulgada pelo regime empresarial-militar em 1976.

A vexata questio, porém, como gostam de dizer os advogados, é que o grande empresariado nacional estava em posições contraditórias num e nou- 


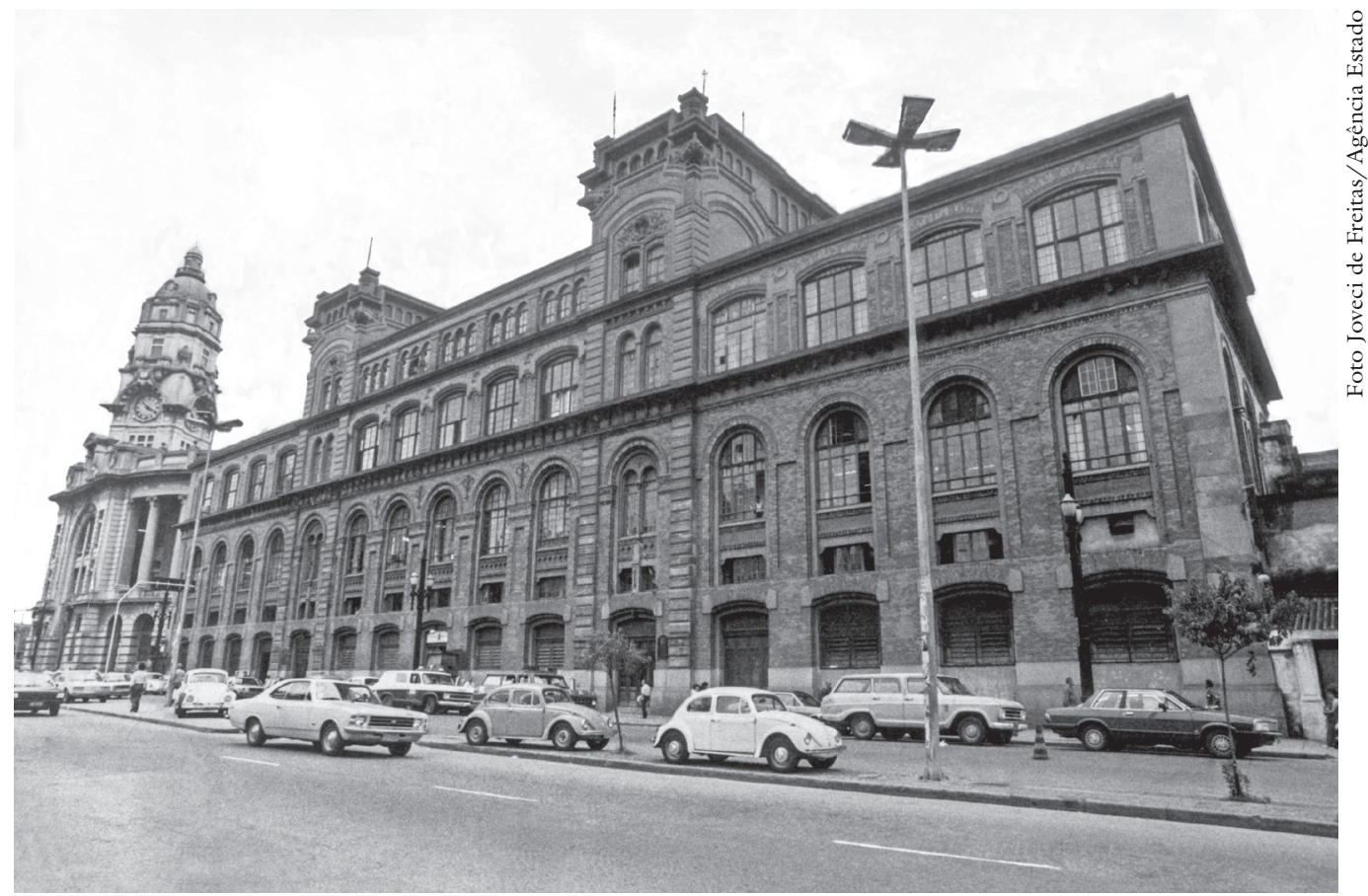

Sede do Dops (Departamento de Ordem Politica e Social) no bairro da Luz, em São Paulo.

tro caso. Enquanto controladores dos principais meios de comunicação social, interessava-lhes que não houvesse nenhuma lei em vigor regulando a matéria. Mas tendo sido colaboradores ativos do regime terrorista, cujos agentes policiais e militares assassinaram e torturaram presos políticos, era indispensável que permanecesse a impunidade imposta pela lei de anistia de 1979. Entre a balança e a espada (símbolos da deusa Têmis da Justiça), a maioria dos membros do Supremo Tribunal preferiu ficar com a espada e jogou a balança no depósito de ferro-velho. O Conselho Federal da Ordem dos Advogados do Brasil (OAB), contudo, não se conformou, e ingressou com recurso, pedindo que o tribunal esclareça se a anistia, cujo período de abrangência encerrou-se em agosto de 1979, aplica-se aos crimes permanentes ou continuados, como o sequestro seguido de morte, com ocultação do cadáver. Até este momento, ainda não houve julgamento do recurso.

De qualquer forma, seis meses após a decisão do Supremo Tribunal a respeito da lei anistia, a Corte Interamericana de Direitos Humanos, em votação unânime, julgou-a contrária ao sistema internacional de direitos humanos.

De minha parte, resolvi abrir nova frente de batalha. Redigi um anteprojeto de lei interpretativa da lei de anistia, de acordo com o que fora sustentado na ação perante o Supremo Tribunal, e confiei esse anteprojeto à deputada Luciana Genro, que o apresentou oficialmente à Câmara dos Deputados. Infelizmente, como a deputada não foi reeleita na seguinte legislatura, pedi à deputada Luiza Erundina que o reapresentasse, o que foi feito. Como era de esperar, a direita raivosa tomou a iniciativa de atropelar o Regimento Interno da Câmara e, antes 
da apreciação do projeto de lei na Comissão de Constituição, Justiça e Cidadania, resolveu encaminhá-lo à Comissão de Relações Exteriores (!), onde ele foi liminarmente rejeitado.

Quando criada a Comissão Nacional da Verdade, em novembro de 2011, tive a convicção de que se tratava de um ardil governamental, para fazer esquecer o fato de a Presidência da República ter, vergonhosamente, tomado posição contra a ação judicial proposta pela OAB junto ao Supremo Tribunal Federal, a respeito da lei de anistia de 1979. Grande parte da apuração dos fatos criminosos da repressão política, durante o regime empresarial-militar, já havia sido feita e publicada em livro (Brasil nunca mais - Um relato para a história [Vozes, 1985]), pela arquidiocese de São Paulo, sob a orientação e a responsabilidade de D. Paulo Evaristo Arns e do pastor Jaime Wright. Hoje, minha opinião é menos categórica. A ideia inicial de colocar, lado a lado, os algozes e as vítimas do regime terrorista foi afastada. Aliás, já me servi da Comissão para pressionar a Procuradoria da República em Brasília a dar sequência a uma representação que apresentei, sobre a declaração de autoridades governamentais de que os documentos militares sobre os fatos da repressão haviam sido incinerados. Como se sabe, a destruição de documentos públicos constitui um crime, definido no art. 314 do Código Penal.

Verifico, ainda, que a criação de múltiplas comissões da verdade, inclusive na USP, tem contribuído para pôr em foco, cada vez mais, os horrores praticados durante aqueles tenebrosos vinte anos, estimulando as manifestações de "escracho" de grupos de jovens contra os criminosos impunes.

\section{Grande imprensa}

EA - Como se importou a chamada grande imprensa em face da ditadura militar e de seus horrores?

FKC - Já lembrei que os principais meios de comunicação de massa, em nosso país, estão submetidos ao controle de um oligopólio empresarial, e que o grande empresariado, seguindo a tradição do poder capitalista, atuou na sombra para apoiar os militares, sobretudo financeiramente. Como assinalou Elio Gaspari (A ditadura escancarada [Cia. das Letras, 2002, p.62]), no segundo semestre de 1969 os banqueiros de São Paulo, convocados por Delfim Neto, decidiram financiar a criação da Operação Bandeirante, responsável por um sem-número de assassínios e torturas. Obviamente, defender o regime político de então sempre foi a preocupação, não só dos donos de grandes jornais e revistas, de emissoras de rádio e televisão, mas do empresariado em geral.

O que custei a compreender é que os piores veículos de comunicação, a esse respeito, eram os que se fantasiavam de progressistas.

Quero referir-me ao episódio em que fui envolvido em fevereiro de 2009, com o jornal Folha de S.Paulo. Em editorial publicado na edição de 17 de fevereiro de 2009, intitulado "Limites a Chávez", sustentou aquele periódico que o regime empresarial-militar no Brasil, quando comparado com outros países 
latino-americanos, havia sido uma "ditabranda". Como não leio editoriais, só em 19 de fevereiro tomei conhecimento de uma carta indignada do Sr. Sérgio Pinheiro Lopes, leitor de Minas Gerais, a respeito da posição ostentada pelo jornal. Aí, meu sangue ferveu nas veias, e enviei também uma missiva, do seguinte teor:

"O leitor Sérgio Pinheiro Lopes tem carradas de razão.

O autor do vergonhoso editorial de 17 de fevereiro, bem como o diretor que o aprovou deveriam ser condenados a ficar de joelhos em praça pública e pedir perdão ao povo brasileiro, cuja dignidade foi descaradamente enxovalhada.

Podemos brincar com tudo, menos com o respeito devido à pessoa humana."

Como eu, vários outros leitores, entre os quais a professora Maria Victoria Benevides, enviaram seus protestos ao jornal. As cartas (não sei se todas elas) foram publicadas sem comentários. A minha e a da professora Maria Victoria, porém, apareceram com a seguinte nota da redação do jornal:

"Nota da Redação - A Folha respeita a opinião de leitores que discordam da qualificação aplicada em editorial ao regime militar brasileiro e publica algumas dessas manifestações acima. Quanto aos professores Comparato e Benevides, figuras públicas que até hoje não expressaram repúdio a ditaduras de esquerda, como aquela ainda vigente em Cuba, sua 'indignação' é obviamente cínica e mentirosa."

Diante da onda crescente de protestos públicos contra o jornal, o diretor de redação foi obrigado a reconhecer, na edição de 8 de março seguinte, que a expressão "ditabranda", usada no editorial do dia 17 de fevereiro, havia sido "um erro". Mas aproveitou a oportunidade para qualificar a professora Maria Victoria e eu como "democratas de fachada".

Acontece que, para infelicidade do jornal, o seu ombudsman de então, jornalista Carlos Eduardo Lins da Silva, fez questão de corrigir o diretor de redação, em 15 de março seguinte, como segue:

“A propósito, leitores registram que a 'Nota da Redação' em resposta a carta de Fábio Konder Comparato em 20 de fevereiro continha erro factual. É verdade: ela dizia que Comparato não havia 'até hoje' manifestado repúdio a ditaduras de esquerda como a de Cuba. Em $1^{\circ}$ de junho de 2004, o 'Painel do Leitor' publicou carta dele com críticas ao regime cubano."

Diante disso, decidi-me a propor contra o jornal uma ação de danos morais. Pois bem, perdi em primeira instância e também no Tribunal de Justiça por unanimidade. Recolhi-me, então, aos meus penates, para meditar sobre minha incapacidade, durante dezenas de anos de advocacia, em perceber a subserviência da maior parte dos magistrados ao poder dos meios de comunicação de massa.

EA - Quais os objetivos e os resultados efetivos da Escola de Governo?

FKC - A Escola de Governo foi fundada em 1990 e começou a funcionar no ano seguinte. Nesse empreendimento educacional, contei com a colaboração 
inestimável de meus grandes amigos, professores Maria Victoria de Mesquita Benevides e Claudineu de Melo, não só nas funções docentes, mas também na parte de gestão administrativa, onde minha incapacidade é manifesta.

A razão justificativa da criação dessa Escola me pareceu à época das mais evidentes. Se no mundo moderno considera-se que grande número de profissões privadas, pela sua importância e complexidade, exige uma formação profissional adequada, muitas vezes sancionada obrigatoriamente por um diploma, é incompreensível que o exercício da mais importante e abrangente das funções públicas - o governo do Estado - seja confiado a pessoas despreparadas. A criação da Escola de Governo em São Paulo me pareceu uma forma, embora modesta, de se difundir a ideia da necessidade de uma adequada preparação para o exercício das funções políticas. A Escola mantém convênio cultural com a USP, através da Faculdade de Educação, e funciona no Centro Cultural da Rua Maria Antonia.

Logo nos primeiros anos que se seguiram à fundação da Escola em São Paulo, várias outras instituições da mesma espécie foram criadas em outros Estados da federação, quase todas filiadas à nossa Escola. Com a promulgação da Emenda Constitucional no 19, de 1998, que instituiu a Reforma Administrativa do Estado, determinou-se que "a União, os Estados e o Distrito Federal manterão escolas de governo para a formação e o aperfeiçoamento dos servidores públicos, constituindo-se a participação nos cursos um dos requisitos para a promoção na carreira, facultada, para isso, a celebração de convênios ou contratos entre os entes federados" (Constituição Federal, art. 39, $\$ 2^{\circ}$ ). A proposta dessa Reforma Administrativa foi feita pelo professor Bresser-Pereira, então ministro no governo do presidente Fernando Henrique Cardoso, e que havia participado das discussões iniciais para a criação da Escola, chegando a ministrar algumas aulas no curso regular de formação de governantes.

Inicialmente, o propósito era instruir os atuais e futuros governantes sobre as técnicas de governo. Em breve, porém, percebemos que o essencial consistia, em lugar de uma mera instrução técnica, em realizar uma verdadeira educação política, fundada nos grandes princípios da República, isto é, da supremacia do bem comum do povo sobre todo e qualquer interesse particular; da Democracia, isto é, da soberania efetiva e não apenas retórica do povo; e do Estado de Direito, ou seja, do exercício controlado de toda espécie de poder, inclusive o soberano, a fim de se evitarem desvios e abusos O objetivo da Escola de Governo, portanto, nos últimos anos, passou a ser a formação de cidadãos politicamente ativos e responsáveis.

Ao cabo de vinte anos, durante os quais frequentaram os cursos da Escola muitos figurões da política (bons e maus...), além de magistrados, membros do Ministério Público, vários outros agentes do Estado, bem como líderes sindicais e de movimentos sociais, Maria Victoria Benevides, Claudineu de Melo e eu próprio decidimos confiar a direção da entidade a uma equipe de ex-alunos.

Nesse meio tempo, isto é, entre 2004 e 2010, atuei no Conselho Federal da $\mathrm{OAB}$ em matéria de reforma política. Tive oportunidade de redigir quatro 
sugestões de proposta de emenda constitucional (três delas incluídas em meu livro Rumo à Justiça) e mais de vinte anteprojetos de lei, sugestões em seguida apresentadas ao Congresso Nacional, quase todas aceitas para tramitação oficial. Ao mesmo tempo, convidado por Conselhos Seccionais da $\mathrm{OAB}$ de vários Estados, apresentei análogas propostas no plano estadual e também municipal. Inútil dizer que nenhuma dessas proposições chegou à votação final. Algumas poucas foram liminarmente rejeitadas; quanto às demais, dormem o sono dos justos nos arquivos das Casas Parlamentares.

Afastei-me da $\mathrm{OAB}$, quando percebi que estava perdendo meu latim e jogando o tempo fora. A gota d'água que fez transbordar o vaso foi a rejeição pelo Conselho Federal, no segundo semestre de 2010, de minha proposta para a apresentação, junto ao Supremo Tribunal Federal, de uma ação direta de inconstitucionalidade por omissão, relativamente aos dispositivos constitucionais sobre comunicação social (imprensa, rádio e televisão). O poderoso oligopólio empresarial que domina o setor, além de conseguir fazer com que o Supremo julgasse revogada a lei de imprensa de 1976 (somos atualmente um dos raros países no mundo sem lei de imprensa!), vem impedindo, há 24 anos, que o Congresso dê aplicação efetiva, entre outras, à norma constitucional do art. $220, \mathbb{S} 5^{\circ}$, que pró́be o monopólio e o oligopólio no setor (pudera!); bem como à que regula o conteúdo dos programas de rádio e televisão, no sentido de se dar preferência a finalidades educativas, artísticas, culturais e informativas (art. 221, I). Diante da recusa da OAB em propor a ação, procurei o PSOL e a Confederação Nacional dos Trabalhadores em Publicidade e Comunicação, que imediatamente decidiram ajuizá-la. Fiquei indignado com o governo Dilma, que por intermédio do Advogado Geral da União deu parecer contrário à ação. Mas consolou-me o fato de que a Procuradoria Geral da República manifestou-se em sentido contrário, reconhecendo a omissão inconstitucional do Poder Legislativo em regulamentar a matéria.

\section{Ética}

EA - Qual o eixo teórico do seu opus magnum sobre Ética?

$F K C$ - Ouso dizer que o livro Ética não foi concebido com base em eixos teóricos, mas a partir de sentimentos vitais. As digressões teóricas vieram em seguida, a fim de compor racionalmente esses impulsos do fundo do coração. $\mathrm{O}$ primeiro deles é a busca da felicidade. Como digo na Introdução do livro, nunca se ouviu falar de alguém que tivesse a infelicidade por propósito ou programa de vida. Ora, estou convencido, como procurei argumentar na Parte III do livro, que a felicidade, pessoal ou coletiva, só é alcançada mediante obediência aos princípios éticos da Verdade, da Justiça e do Amor.

O outro grande impulso do coração, que animou a composição da obra, foi a ligação indissolúvel com a Vida e a rejeição absoluta da Morte, por mais absurdos que tais sentimentos pareçam aos olhos da religião ou da fria análise racional. É o que tentei exprimir na conclusão da obra. 
EA - Quais são os seus planos como autor?

FKC - Não gostaria de passar desta para melhor, como se dizia antigamente, sem concluir um novo livro, desta vez sobre o confronto final - decisivo para a Humanidade - entre a presente civilização capitalista e a civilização humanista do futuro. 